modified Ashworth Scale of muscle spasticity. Phys Ther 1987;67:206-7.

13 Leo K, Soderberg G. Relationship between perception of joint position sense and limb synergies in patients with hemiplegia. Phys Ther 1981;61:1433-7.

14 Scholz J. Reliability and validity of the WATSMART ${ }^{\mathrm{TM}}$ three-dimensional optoelectric motion analysis system. Phys Ther 1989;69:679-89.

15 Fitts PM. The information capacity of the human motor system in controlling the amplitude of movement. $\mathcal{F} \operatorname{Exp}$ Pystem in controlling the $1954 ; 47: 381-91$.

16 Wallace SA, Newell KM. Visual control of discrete aiming movements. Quart $\mathcal{f}$ Exp Psychol 1983;35A:311-21.

17 Arbib MA. Schemas for the temporal organization of behaviour. Hum Neurobiol 1985;4:63-72.

18 Georgopoulos AP. On reaching. Ann Rev Neurosci 1986; 9:147-70.

19 Vorro JS, Hobart D. Kinematic and myoelectric analysis of skill acquisition: I. $90 \mathrm{~cm}$ subject group. Arch Phys Med Rehab 1981;62:575-82.

20 Hammond MC, Fitts SS, Kraft GH, Nutter PB, Trotter MJ, Robinson LM. Co-concentration in the hemiparetic forearm: Quantitative EMG evaluation. Arch Phys Med Rehab 1988;69:348-51.

21 Brooks VB, Cooke JD, Thomas JS. The continuity of movements. In: Stein RB, Pearson KG, Smith RS, Redford JB, eds, Control of posture and locomotion. New York: Plenum Press, 1973:257-72.

22 Fetters L, Todd J. Quantitative assessment of infant reaching movements. $\mathcal{f}$ Motor Behav 1987;19:147-66.

23 Siegel S. Nonparametric statistics for the behavioural sciences.
New York: McGraw-Hill, 1956.

24 Snedecor GW, Cochran WG. Statistical methods. 7th edn. Ames: Iowa State University Press, 1980.

25 Wing AM, Miller E. Research Note: Peak velocity timing invariance. Psychol Res 1984;46:121-7.

26 Basmajian JV, DeLuca CJ. Muscles alive: Their functions revealed by electromyography ( 5 th edn). Baltimore: Williams and Wilkins, 1985 .

27 Soechting JF, Lacquaniti F. Coordination of arm and wrist motion during a reaching task. Neurosci 1982;2: mog-408.

28 Nagasaki $H$. Asymmetric velocity and acceleration profiles of human arm movements. Exp Brain Res 1989;74: 319-26.

29 Brooks VB. Some examples of programmed limb movements. Brain Res 1974;71:299-308

30 Winstein CJ. Motor learning considerations in stroke rehabilitation. In: Duncan PW, Badke MB, eds, Stroke rehabilitation: The recovery of motor control. Chicago: Year Book Medical Publishers, 1987:109-34.

31 Hay L. Spatial-temporal analysis of movements in children: Motor programs versus feedback in the development of reaching. F Motor Behav 1979;11:189-200.

32 Bushnell EW. The decline of visually guided reaching during infancy. Infant behaviour and development 1985; 8:139-55

33 Soechting JF, Lacquaniti F. Invarient characteristics of a pointing movement in man. $\mathcal{f}$ Neurosci $1981 ; 1: 710-20$.

34 Van Hofsten C. Development of visually directed reaching: The approach phase. $\mathcal{f}$ Hum Movement Stud 1979;5: 160-78.

\section{John Locke and the trigeminal neuralgia of the Countess of Northumberland}

Although early descriptions of tic douloureux can be inferred from the writings of Avicenna, the most convincing early description was of the suffering physician and philosopher Johannes Laurentius Bausch (1605-65) described by Drs JM Fehr and Elias Schmidt in volume 2 of the published proceedings of the Imperial Leopoldinian Academy of Natural Sciences in $1671 .^{1}$ Of the English contributions, John Locke the famous physician and philosopher described the condition in a series of letters to Dr John Mapletoft in $1677 .^{2}$ The unfortunate patient was the Countess of Northumberland, wife of the Ambassador to France:

Paris, 4th December, 1677

“... On Thursday night last I was sent for to My Lady Ambassadice, whom I found in a fit of such violent and exquisite torment that ... it forced her to such cries and shrieks as you would expect from one upon the rack, to which I believe hers was an equal torment, which extended itself all over the right side of her face and mouth. When the fit came, there was, to use My Lady's own expression of it, as it were a flash of fire all of a suddaine shot into all those parts, and at every one of those twitches made her shreeke out, her mouth was constantly drawn on the right side towards the right eare by repeated convulsive motions ... These violent fits terminated on a suddaine, and then My Lady seemed to be perfectly well ... Speaking was apt to put her into these fits; sometimes opening her mouth to take anything, or touching her gums, especially in places where she used to finde these throbings; pressing the side of her face by lying on it were also apt to put her in these fits. These fits lasted sometimes longer, sometimes shorter . . . at intervals between them not halfe an hower, commonly much shorter..."

Paris, 22 December, '77

"... I believe the drawing of those two teeth, especially the last, hath injur'd some nerve, and soe makes it very apt to be provoked, and draws its neighbours into consent; yet by what My Lady informed me, since violence of her pains have been over, I have reason to suspect there is an ancienter fault in the nerves of that side..."

Later accounts by Wepfer, Nicolaus André (who called it tic douloureux), John and his nephew Samuel Fothergill, and later Charles Bell were to elaborate and elucidate some of the features, possible causes and treatments.

JMS PEARCE

1 Lewy FH. The first authentic case of major trigeminal neuralgia and some comments on the history of this disease. Ann Med Hist 1938;10:247-50.

2 Dewhurst $K$. A symposium on trigeminal neuralgia with contributions by Locke, Sydenham, and other eminent seventeenth century physicians disease. Ann f Hist Med 